\title{
Microbial Treatment of Liquid from Mackerel Waste Juice*1
}

\author{
Md. Abul Hossain, ${ }^{* 2}$ Masayuki Furuichi, ${ }^{* 2}$ and Yasuo Yone*2 \\ (Received March 11, 1988)
}

\begin{abstract}
Yeast Saccharomyces cerevisiae IFO 2114 was cultured in $25 l$ of $75 \%$ sea water containing liquid obtained from mackerel waste juice and molasses (WY) for $48 \mathrm{~h}$, and (1) nitrogen and phosphorus contents in WY medium and (2) proximate and fatty acid compositions of the harvested yeast (WY yeast) were determined. The amount of harvested WY yeast was sufficient to feed rotifers ( $150 \times 10^{8}$ indiv./ton) for a day. Furthermore, the yeast reduced nitrogen and phosphorus contents in the medium to a level which was considered to be safe to discard. On the other hand, WY yeast was higher than yeast cultured in MY medium and baker's yeast and far lower than $\omega$ yeast and marine chlorella in lipid content and percentage of $\omega 3$ HUFA in total fatty acids.
\end{abstract}

In the previous study, ${ }^{11}$ yeast Saccharomyces cerevisiae IFO 2114 showed the best growth in $75 \%$ sea water containing $2.5 \%$ liquid from mackerel waste juice and $1.0 \%$ molasses (WY medium). Therefore, in the present study, in order to investigate the contribution of yeast culture to reduction of an environmental pollution caused by the discarding of the liquid, the yeast culture in sea water with the liquid was conducted on a large scale and nitrogen and phosphorus contents in the medium after cultivation were determined. Furthermore, the comparisons of proximate and fatty acid compositions were made among the yeasts cultured in WY medium (WY) and MY medium (MY), ${ }^{1}$ commercial baker's yeast (BY), $\omega$-yeast (Kyowa Hakko Kogyo Co. Ltd., $\omega Y)^{22}$ and marine chlorella Chlorella minutissima.

\section{Materials and Methods}

\section{Liquid}

The liquid obtained from mackerel waste juice in the previous study ${ }^{1)}$ was used after sterilization.

\section{Yeast Seed}

Saccharomyces cerevisiae IFO 2114 cultured on a MY agar slant medium was inoculated into $500 \mathrm{~m} l$ of MY broth medium in a $1 l$ flask and was cultured at $28-30^{\circ} \mathrm{C}$ for $36 \mathrm{~h}$ by shaking in a water bath with reciprocal shaker.

\section{Propagation and Harvest}

Two $30 l$ polyvinyl tanks which were fitted up with a 100 watts heater and a motorized propeller of 2,000 rpm capacity were used for the propagation of yeast. Twenty five litres of MY medium was added in one tank and the same volume of $75 \%$ sea water containing $2.5 \%$ liquid and $1.0 \%$ molasses (WY medium) was added in the other. Yeast seed was inoculated at a rate of 5.0 million cells $/ \mathrm{m} l$ to both tanks, respectively, and was cultured at $30^{\circ} \mathrm{C}$ for $48 \mathrm{~h}$ under stirring and strong aerating.

After culturing, yeast cells were counted by a hemacytometer. Then, the aeration and stirring were stopped for $4-5 \mathrm{~h}$ to deposit the cells at the bottom of culture tanks. The cells were siphoned out and centrifuged at $2,000 \mathrm{rpm}$ for $10 \mathrm{~min}$. Siphoning was done repeatedly until almost no cells were found in the culture medium microscopically. Finally harvested cells were weighed.

\section{Analytical Methods}

The determinations of nitrogen and phosphorus contents in media before and after cultivations of the yeast were done by the same methods as mentioned in the previous paper. ${ }^{1)}$ The proximate and fatty acid compositions of cultured yeast were determined by the same methods as described in the previous studies, ${ }^{3}{ }^{47}$ except the column temperature of $175^{\circ} \mathrm{C}$ in fatty acid analysis.

*1 Contribution from Fish. Res. Lab., Kyushu University, No. 174. Studies on Utilization of Fish Waste -8 .

*2 Fishery Research Laboratory, Kyushu University, Tsuyazaki, Fukuoka 811-33, Japan (モハメト アブル ホセイン，古市政市，米康夫：九州大学裳学部附属水産実驗所). 


\section{Results and Discussion}

Growth of Yeast and Changes of Nitrogen and Phosphorus Contents in Medium

As shown in Table 1, WY yeast showed lower density and harvest than those of MY yeast. However, the amount of yeast required for $10^{6}$ rotifers is $1-1.5 \mathrm{~g}$ for a day. Therefore, the amount of yeast cultured in $25 l \mathrm{WY}$ medium for $48 \mathrm{~h}$ (about $218 \mathrm{~g}$ ) is sufficient as a feed for rotifers in 1 ton tank for a day or more, if rotifer density doesn't exceed 150 indiv. $/ \mathrm{m} l{ }^{3}$ )

Table 1. Growth of yeast and changes of nitrogen and phosphorus contents in medium

\begin{tabular}{llrr}
\hline \multicolumn{1}{c}{ Medium } & & MY & \multicolumn{1}{c}{ WY* $^{*}$} \\
\hline Density of yeast & at start & 5.0 & 5.0 \\
$\left(\times 10^{8}\right.$ cells $\left./ \mathrm{m} l\right)$ & after $48 \mathrm{~h}$ & 69.1 & 50.5 \\
Yeast harvested & wet $\mathrm{wt}$. & 408.9 & 217.8 \\
(after $48 \mathrm{~h}, \mathrm{~g})$ & dry wt. & 80.8 & 54.9 \\
Total nitrogen & at start & 188.2 & 162.1 \\
$(\mu \mathrm{g}$ atom $l)$ & after $48 \mathrm{~h}$ & 20.3 & 11.2 \\
Total phosphorus & at start & 222.5 & 117.6 \\
$(\mu$ g atom $l)$ & after $48 \mathrm{~h}$ & 29.0 & 14.9 \\
\hline Diluted sea water with liquid from mackerel waste $(2.5 \%)$ and \\
molasses $(1.0 \%)$.
\end{tabular}

On the other hand, the nitrogen and phosphorus in MY and WY culture media decreased remarkably. Namely, the decreases of nitrogen were 89.2 and $93.1 \%$ of the initial contents, respectively, and the phosphorus were 87.0 and $87.3 \%$.

These findings indicate that yeast utilizes the nitrogen and phosphorus in the liquid of fish waste as nutrient sources and that the yeast culture can decrease the pollution caused by the release of waste juice.

\section{Proximate and Fatty Acid Compositions of Yeast Cultured}

The proximate composition of WY yeast was different from those of BY yeast, MY yeast and $\omega$ yeast (Table 2). Namely, WY yeast showed low protein and high lipid contents as compared with BY and MY yeasts, but the protein content was higher than $\omega$ yeast and the lipid content was far lower. The fatty acid compositions of yeasts and marine chlorella are shown in Table 3. The percentage of $\omega 3$ highly unsaturated fatty acids with more than 20 carbons ( $\omega 3$ HUFA) in total fatty acids of WY yeast was high as compared with those of MY and BY yeasts, but it was con-
Table 2. Proximate compositions of baker's yeast (BY), $\omega$-yeast $(\omega Y)$, and yeasts cultured in MY and WY media

\begin{tabular}{lccccc}
\hline \multicolumn{2}{c}{ Yeast } & BY & MY & WY & $\omega Y$ \\
\hline \multicolumn{2}{c}{ Moisture (\%) } & 66.8 & 76.8 & 75.5 & 61.9 \\
Lipid* & $(\%)$ & 2.2 & 1.9 & 2.5 & 13.2 \\
& & $(6.6)$ & $(8.2)$ & $(10.2)$ & $(34.6)$ \\
Protein* & $(\%)$ & 17.0 & 11.4 & 10.9 & 15.4 \\
\multirow{4}{*}{ Ash* } & $(\%)$ & $(51.2)$ & $(49.1)$ & $(44.5)$ & $(40.4)$ \\
& & $(5.8$ & 2.0 & 2.0 & 2.1 \\
& & $(5.4)$ & $(8.6)$ & $(8.2)$ & $(5.5)$ \\
\hline
\end{tabular}

* Values in parenthesis indicate \% dry matter basis.

Table 3. Fatty acid compositions in lipids of yeasts cultured in MY and WY media, baker's yeast (BY), $\omega$-yeast ( $\omega \mathrm{Y})$ and marine chlorella

\begin{tabular}{|c|c|c|c|c|c|}
\hline \multirow{2}{*}{ Fatty acid } & \multicolumn{5}{|c|}{ Yeast } \\
\hline & BY & MY & WY & $\omega \mathrm{Y}$ & chlorella \\
\hline $12: 0$ & $0.1^{*}$ & 0.6 & 0.3 & 0.4 & 1.0 \\
\hline $13: 0$ & 0.1 & 0.5 & 0.3 & 0.2 & 0.9 \\
\hline $14: 0$ & 0.6 & 6.6 & 8.7 & 4.6 & 5.0 \\
\hline $15: 0$ & 0.5 & 1.5 & 1.3 & 0.5 & 0.8 \\
\hline $16: 0$ & 8.7 & 28.0 & 22.7 & 13.3 & 18.9 \\
\hline $16: 1 \omega 7$ & 22.7 & 14.8 & 7.0 & 4.8 & 22.2 \\
\hline $18: 0$ & 7.8 & 6.4 & 7.0 & 2.7 & 0.3 \\
\hline $18: 1 \omega 9$ & 40.6 & 13.7 & 20.4 & 14.7 & 4.6 \\
\hline $18: 2 \omega 9$ & 0.9 & $\operatorname{tr}$ & 0.7 & $\operatorname{tr}$ & - \\
\hline $18: 2 \omega 6$ & 5.6 & 3.8 & 1.3 & 1.4 & 2.1 \\
\hline $18: 3 \omega 3$ & tr & 0.7 & tr & 1.2 & 一 \\
\hline $20: 1$ & 3.2 & 1.9 & 1.2 & 7.3 & - \\
\hline $20: 1 \omega 9$ & - & - & 9.8 & - & - \\
\hline $20: 1 \omega 7$ & 0.8 & 0.1 & 0.2 & tr & 一 \\
\hline $20: 2 \omega 9$ & 1.0 & 0.3 & 0.1 & 2.1 & - \\
\hline $20: 2 \omega 6$ & - & - & 一 & 0.9 & - \\
\hline $20: 3 \omega 3$ & - & - & - & 0.3 & 0.8 \\
\hline $20: 4 \omega 3$ & 0.5 & 0.1 & 0.5 & 1.6 & 6.9 \\
\hline $20: 5 \omega 3$ & - & 0.9 & 1.4 & 10.6 & 28.9 \\
\hline $22: 1$ & 0.5 & 1.8 & 8.7 & 8.2 & - \\
\hline $22: 4 \omega 6$ & - & 0.8 & - & - & - \\
\hline $22: 5 \omega 6$ & 一 & - & 2.0 & 2.6 & - \\
\hline $22: 5 \omega 3$ & - & - & 0.2 & 1.9 & - \\
\hline $22: 6 \omega 3$ & 一 & - & 0.6 & 15.3 & - \\
\hline$\overline{\Sigma \omega} 3$ HUFA & 0.5 & 1.0 & 2.7 & 29.7 & 36.6 \\
\hline
\end{tabular}

siderably lower than those of $\omega$ yeast and marine chlorella.

From these results, the nutritive value of yeast cultured in sea water containing the liquid from mackerel waste and molasses for $48 \mathrm{~h}$ (WY) seems to be higher than that of commercial baker's yeast, because of higher $\omega 3$ HUFA content. However, it is doubtful whether WY yeast is suitable to feed rotifers or not. 


\section{References}

1) M. A. Hossain, M. Furuichi, and Y. Yone: Nippon Suisan Gakkaishi, 54, 469-471 (1988).

2) O. Imada, Y. Kageyama, T. Watanabe, C. Kitajima, S. Fujita, and Y. Yone: Nippon Suisan Gakkaishi, 45, 955-959 (1979).
3) Y. Yone, M. A. Hossain, M. Furuichi, and F. Kato: Nippon Suisan Gakkaishi, 52, 549-552 (1986).

4) M. A. Hossain, M. Furuichi, and Y. Yone: Nippon Suisan Gakkaishi, 53, 1629-1632 (1987).

5) T. Watanabe, T. Tamiya, A. Oka, M. Hirata, C. Kitajima, and S. Fujita: Nippon Suisan Gakkaishi, 49, 471-479 (1983). 